\title{
Microstructure Evolution of the Mg-5.8 Zn-0.5 Zr-1.0 Yb Alloy During Homogenization
}

\author{
Lu Li ${ }^{a *}$, Wei Jiang ${ }^{a}$, Pei-tao Guo ${ }^{a}$, Wen-bin Yu ${ }^{a}$, Fang Wang ${ }^{a}$, Zhi-yuan Pan ${ }^{a}$ \\ ${ }^{a}$ Faculty of Materials and Energy, Southwest University, Chongqing 400715, PR China
}

Received: December 19, 2016; Revised: April 15, 2017; Accepted: May 22, 2017

\begin{abstract}
The influence of homogenization treatment on microstructure evolution of $\mathrm{Mg}-5.8 \mathrm{Zn}-0.5 \mathrm{Zr}-1.0 \mathrm{Yb}$ (mass fraction, \%) alloy was investigated under different annealing temperatures and holding times. Results indicated a severe dendritic segregation in the as-cast ingot. $\mathrm{Zn}$ and $\mathrm{Yb}$ segregate remarkably at the grain boundary and $\mathrm{Zr}$ appears in the form of precipitates. The $\mathrm{Mg}-\mathrm{Zn}$ binary eutectic phases and a new ternary phase $\mathrm{Mg}-\mathrm{Zn}-\mathrm{Yb}$ are mainly distributed at dendrite boundaries. After homogenization, most of the eutectic phases dissolve into the matrix, except for a small amount of $\mathrm{Mg}-\mathrm{Zn}-\mathrm{Yb}$ phase. The area fractions of residual secondary phase decrease from $5.54 \%$ in the as-cast alloy to $0.59 \%$ in the well-homogenized sample. Microhardness test indicates that with the increasing temperature and holding time, microhardness value decreased sharply within the first stage of homogenization and then increased steadily to the local maximum value at $380^{\circ} \mathrm{C}$ and $12 \mathrm{~h}$, followed by a slight reduction. Basing on the comprehensive analysis on microstructure and mechanical properties, the homogenization treatment at $380{ }^{\circ} \mathrm{C}$ for $12 \mathrm{~h}$ is preferable.
\end{abstract}

Keywords: $M g-Z n-Z r$ alloy, Ytterbium, Homogenization, Microstructure

\section{Introduction}

Magnesium alloy is among the lightest metallic construction materials and has attracted considerable attention in automobile and aircraft applications owing to its readily available properties, low density, high specific strength, and stiffness ${ }^{1}$. However, the low-strength and poor ductility of traditional wrought $\mathrm{Mg}$ alloys at room temperature have limited their application ${ }^{2,3}$.

Many endeavors have been devoted to developing highperformance wrought magnesium alloys by alloying small additions of rare-earth elements, such as Er, La, Y, Nd, Gd, and misch metal ${ }^{4-8}$, to commercial wrought magnesium alloys. In recent years, the heavy rare-earth element ytterbium $(\mathrm{Yb})$ has attracted significant interest as an effective alloying additive. The grain refinement effect is the most important function of $\mathrm{Yb}$ addition ${ }^{9-11}$. Unlike other elements, such as $\mathrm{Zr}$ in magnesium alloys or $\mathrm{Ti}$ in aluminum alloys, which increase grain coarsening resistance by heterogeneous nucleus in peritectic reaction ${ }^{12}$, Yb refines microstructures mainly due to constitutional undercooling ${ }^{11}$. Moreover, the precipitation strengthening effects of $\mathrm{Yb}$-rich precipitates are the most promising approach to developing high-performance alloys. Upon heat treatment, nano-scale precipitates with high density and homogeneity are observed in $\mathrm{Mg}-\mathrm{Zn}-\mathrm{Yb}^{13-15}$, $\mathrm{Al}-\mathrm{Li}-\mathrm{Sc}-\mathrm{Yb}^{16}, \mathrm{Al}-\mathrm{Cu}-\mathrm{Mg}-\mathrm{Ag}-\mathrm{Yb}^{10}$, and $\mathrm{Al}-\mathrm{Zn}-\mathrm{Mg}-\mathrm{Cu}-$ $\mathrm{Yb}^{17-18}$ systems. Furthermore, a morphological evolution of precipitates or secondary phases is achieved by adding appropriate amount of $\mathrm{Yb}^{19-21}$. Consequently, alloys with $\mathrm{Yb}$ modification exhibit enhanced performances in terms

*e-mail: lilu.swu@gmail.com of mechanical properties ${ }^{11,15,19}$, corrosion resistance ${ }^{13,18,22}$, and thermal stability ${ }^{10,21}$ compared with the unmodified counterparts.

Reducing or eliminating microstructure and composition segregation caused by non-equilibrium crystallization are the main purposes of the homogenization treatment for as-cast parts. Deformation behavior of alloys is substantially affected by morphology, density, or distribution of initial intermetallic compounds and undissolved particles in the cast alloys, which may induce local stress concentration or hinder dynamic recrystallization. The mechanical properties of magnesium alloys are considerably improved after homogenization treatment. Zhao et al reported a considerable increase of ultimate tensile strength by $\sim 65 \%$ and percentage elongation by $\sim 110 \%$ with no obvious loss of corrosion performance in homogenized as-cast Mg-8.26 Al-0.69 Zn (wt.\%) alloy ${ }^{23}$. Comparing with the as-cast sample, the researchers found that the mechanical properties after homogenization were obviously improved because of the absence of a continuous easy crack path ${ }^{24}$. For the reasons mentioned above, homogenization treatment is extensively applied to as-cast alloys prior to deformation. Moreover, due to the presence of coarse dendrites and continuous precipitates in $\mathrm{Mg}-\mathrm{Zn}$ alloys, performing homogenization treatment on magnesium alloys is preferable.

Recent studies focused mostly on microstructure and mechanical properties under the aged and deformed $\mathrm{Yb}$ containing alloys ${ }^{15,19,20,22}$. However, few reports are available concerning the homogenization treatment on $\mathrm{Mg}-\mathrm{Zn}-\mathrm{Yb}$ alloys. This phenomenon is mainly due to the considerable chemical inhomogeneity caused by the big difference in melting 
temperature and diffusion rate of $\mathrm{Mg}, \mathrm{Zn}, \mathrm{Zr}$, and $\mathrm{Yb}$. Verifying the microstructure evolution from as-cast to as-homogenized alloys and revealing the strengthening mechanism in the newly developed $\mathrm{Mg}-\mathrm{Zn}-\mathrm{Yb}$ alloy are important. Basing on the consideration above, this paper aims at studying the influence of homogenization treatment on microstructures and properties of Mg-5.8 Zn-0.5 Zr-1.0 Yb alloy. Toward this end, a series of homogenization-treatment tests were performed at different annealing temperatures and holding times. The transformation process of primary eutectic structures and composition distribution of $\mathrm{Mg}, \mathrm{Zn}, \mathrm{Zr}$, and $\mathrm{Yb}$ during as-cast and as-homogenized were examined systematically. The mechanical property of the $\mathrm{Yb}$ incorporated samples after heat treatment was evaluated by microhardness measurements at the micro-level. The modification effects of $\mathrm{Yb}$ on the microstructure evolution and mechanical properties were discussed.

\section{Experimental Details}

Pure magnesium and pure zinc, master alloys of $\mathrm{Mg}-15 \% \mathrm{Yb}$ and $\mathrm{Mg}-30 \% \mathrm{Zr}$ (all in wt \%) were chosen as raw materials to prepare the $\mathrm{Mg}-5.8 \mathrm{Zn}-0.5 \mathrm{Zr}-1.0 \mathrm{Yb}$ alloys. The alloys were melted in an electric furnace with a graphite crucible under flux protection, and then the melt was poured into the $200{ }^{\circ} \mathrm{C}$ pre-heated permanent mold to prepare ingots with sizes of $\Phi 15 \mathrm{~mm} \times 100 \mathrm{~mm}$. In order to focus on the identification of potential $\mathrm{Yb}$-containing precipitates during homogenization treatment and then revealing the strengthening effects induced by the novel $\mathrm{Mg}-\mathrm{Zn}-\mathrm{Yb}$ ternary system, the annealing temperatures were set to higher than the eutectic temperature of $\mathrm{Mg}-\mathrm{Zn}$ binary alloy $\left(340{ }^{\circ} \mathrm{C}\right)^{25}$, which can reduce the influence of $\mathrm{Mg}-\mathrm{Zn}$ binary precipitates. The alloys were heated at 360 , $380,400,420$, and $440^{\circ} \mathrm{C}$, and held for different times of 4 , $8,12,16,20$ and $24 \mathrm{~h}$, then quenched in water to preserve the high-temperature microstructures.

As-cast alloys were etched by $4 \mathrm{~mL}$ nitric acid and $96 \mathrm{~mL}$ alcohol. All the heat-treated specimens were etched with an etchant of $4 \mathrm{~mL}$ picric acid, $6 \mathrm{~mL}$ acetic acid, $80 \mathrm{~mL}$ alcohol, and $10 \mathrm{~mL}$ water for $25 \mathrm{~s}$ to $30 \mathrm{~s}$. Microstructures of the alloys were observed by using an optical microscope and a scanning electron microscope (SEM, Sirion 200) equipped with an energy-dispersive spectrometer (EDS, GENESIS 60S). DSC analysis was performed on an STA-409 PC differential scanning calorimeter. Line scanning analysis was performed to observe the distribution of the alloying elements in the specimens. Vickers microhardness was measured under different homogenization conditions. The phase constituent analysis was performed by X-ray diffraction (XRD, Rigaku D/Max 2500). The specimens both as-cast and as-homogenized were subjected to image analysis. The average area of the undissolved secondary phases was measured by Image-Pro Plus software, and each reading was an average of 10 separate measurements in a random field.

\section{Results and Discussion}

\subsection{Characterization of as-cast microstructure}

Figure 1(a) exhibits the optical micrograph of the as-cast sample. The dendrites are separated by the coarse nonequilibrium phases. The mean size of dendritic grains is $\sim 93.8$ $\mu \mathrm{m}$. Figure 1(b) presents the back-scattered SEM image. The white eutectic phases with morphology of discontinuous networks or granules distributed along the $\alpha$-Mg dendrite boundaries substantially degrade the mechanical properties of the alloy because of the hereditary microstructure. The grain refinement effect of $\mathrm{Yb}$ in magnesium alloys has been reported in many studies ${ }^{9,11}$. However, as shown in Figure 1 , the typical dendritic grain morphology and large grain size of the cast microstructure reveal that the modification of $\mathrm{Yb}$ does not occur in the studied Mg-5.8 Zn-0.5 Zr-1.0 $\mathrm{Yb}$ as-cast alloys. The main reason is probably because the content of $\mathrm{Yb}$ in the studied alloy is as low as 1.0 at.\%. Consequently, the constitutional undercooling generated by an increase in solute gradients corresponding to $\mathrm{Yb}$ and other solute atoms is fairly limited, which results in an increased diffusion rate, a decreased nuclei density, and restricted grain growth. Therefore, the modifying effect of $\mathrm{Yb}$ intensifies provided that the content reaches a certain level.

The energy dispersive X-ray spectroscopy (EDS) is utilized to analyze the phase constitution of the as-cast alloys. The SEM image of typical intermetallic phases in as-cast structure is shown in Figure 2(a), and the compositions of six points detected by EDS are shown in Table 1. The contents of $\mathrm{Zr}$ and $\mathrm{Yb}$ are all below 0.30 at.\% in points $A, B$, and $D$, and the intermetallic phases all mainly consist of $\mathrm{Mg}$ and $\mathrm{Zn}$. The atomic ratios of $\mathrm{Mg}$ to $\mathrm{Zn}$ of points $A, B$, and $D$ are close to $1: 2,1: 1$, and 7:3, considered as $\mathrm{MgZn}_{2}, \mathrm{MgZn}$, and $\mathrm{Mg}_{7} \mathrm{Zn}_{3}$ phases, respectively. In addition, the white round particle in the grain interior, marked as $E$, is rich in $\mathrm{Mg}$ and $\mathrm{Zr}$ and lack $\mathrm{Zn}$ and $\mathrm{Yb}$. $E$ is determined as the $\mathrm{Zr}$-rich particle which acts as a grain refiner in magnesium alloys. However, the isolated island-shaped particle marked as $C$ is comprised of $\mathrm{Mg}, \mathrm{Zn}$, and $\mathrm{Yb}$ and the atomic ratio of $\mathrm{Zn}$ and $\mathrm{Yb}$ is close to 5:1, which is identified as $\mathrm{Mg}_{x} \mathrm{Zn}_{5} \mathrm{Yb}$ based on the reference ${ }^{15}$. Furthermore, the $\mathrm{Mg}-\mathrm{Zn}-\mathrm{Yb}$ ternary phase is not observed in the XRD patterns (Figure 3) mainly because of the low content. The composition profile along the line across the coarse particle is shown in Figure 2(b). The phase with the lamellar structure is rich in $\mathrm{Mg}$ and $\mathrm{Zn}$ but scarce in $\mathrm{Zr}$ and $\mathrm{Yb}$, as represented by $\mathrm{Zn}$-rich rings at the grain boundaries. Moreover, EDS point detection indicates that the $\mathrm{Zr}$ - and $\mathrm{Yb}$ rich phases are mostly far from coarse particles. Zr-containing particles are usually observed in grain interior which serve as the core of heterogeneous nucleation. Furthermore, Yb-rich phases are mostly detected at grain boundaries with an approximately spherical morphology. Consequently, the secondary phases in the as-cast alloy include $\mathrm{Mg}-\mathrm{Zn}$ binary $\left(\mathrm{MgZn}_{2}, \mathrm{MgZn}\right.$, and $\left.\mathrm{Mg}_{7} \mathrm{Zn}_{3}\right), \mathrm{Mg}-\mathrm{Zn}-\mathrm{Yb}$ ternary $\left(\mathrm{Mg}_{\mathrm{x}} \mathrm{Zn}_{5} \mathrm{Yb}\right)$, and $\mathrm{Zr}$-rich particles. 

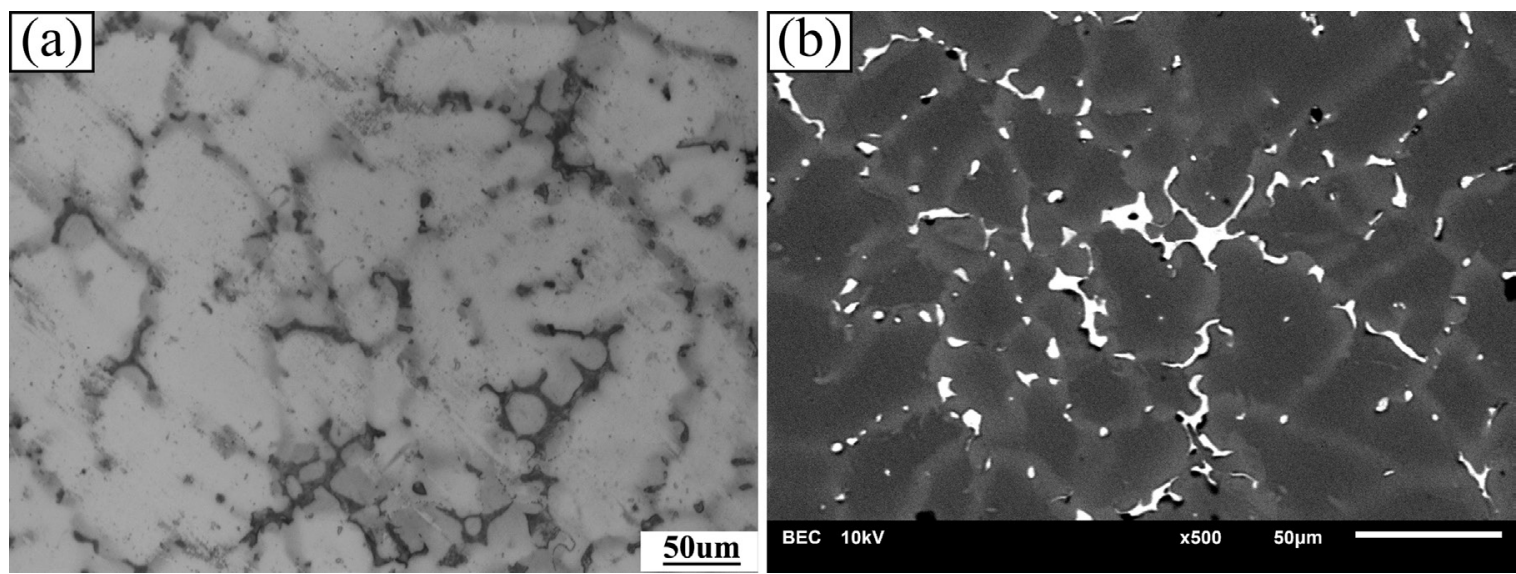

Figure 1. OM image (a) and back-scattered SEM image (b) of as-cast alloys.

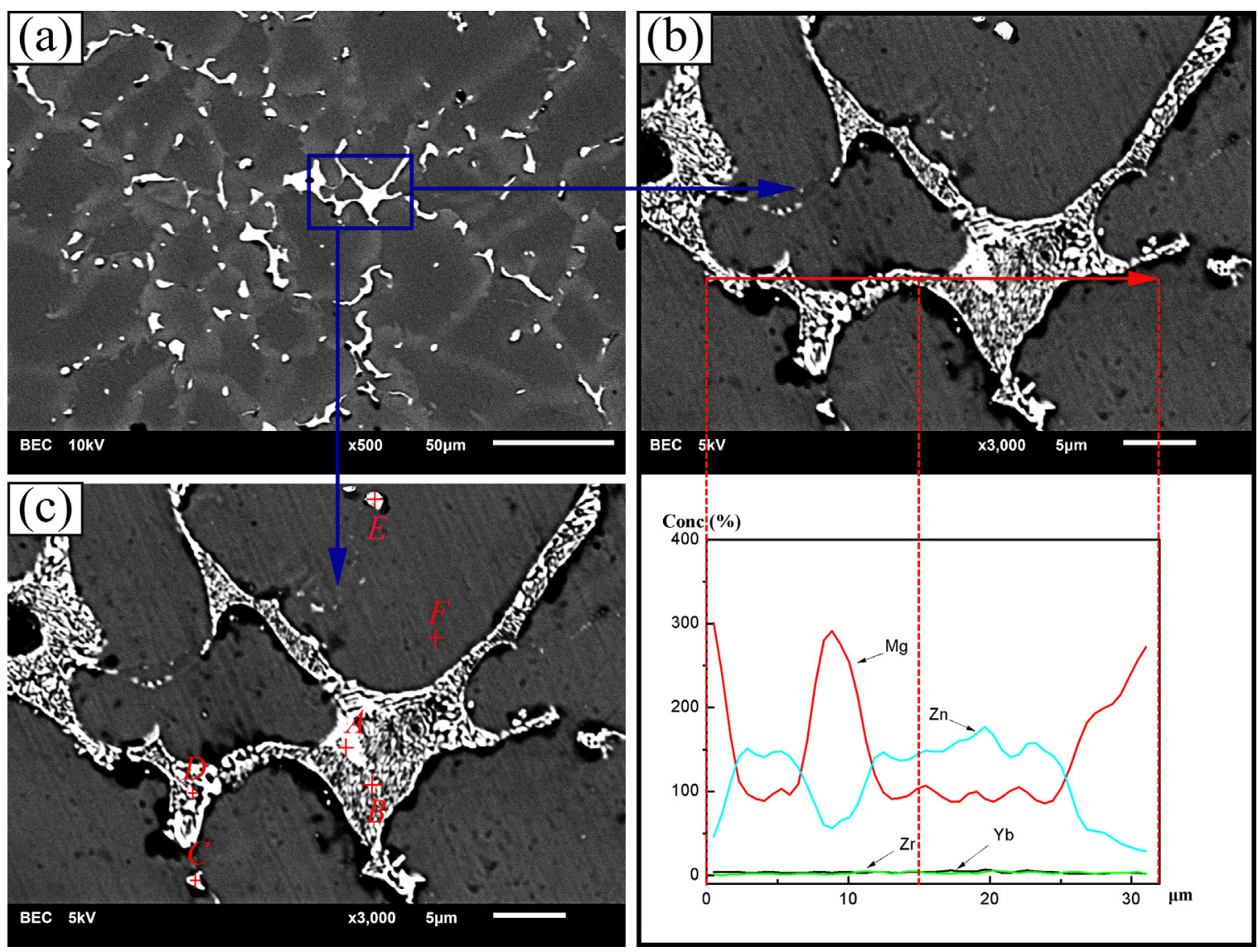

Figure 2. (a) SEM image of the phase constitution in the as-cast structure, (b) concentration profile of the composition across the coarse phase and (c) high magnification image of the selected area in (a), measured by EDS.

\subsection{XRD and DSC analysis}

Figure 3 shows the XRD patterns of as-cast and homogenized alloys. It indicates that besides the matrix $\alpha(\mathrm{Mg})$, the main secondary phase in the as-cast sample is $\mathrm{MgZn}_{2}$. After homogenization at $380^{\circ} \mathrm{C}$ for $12 \mathrm{~h}$, the $\mathrm{MgZn}_{2}$ phase disappeared and only the matrix $\alpha(\mathrm{Mg})$ remained. As shown in Figure 3, however, none of the $\mathrm{Yb}$ - or $\mathrm{Zr}$-containing phases were detected by XRD due to the low content of $\mathrm{Yb}$ and the limited solubility of $\mathrm{Zr}$ in the $\mathrm{Mg}$ matrix.

DSC curves of as-cast and $380^{\circ} \mathrm{C} \times 12 \mathrm{~h}$ homogenized Mg-5.8 Zn-0.5 Zr-1.0 Yb alloys are shown in Figure 4. Two endothermic peaks appearing at temperatures of approximately 354.7 and $389.3^{\circ} \mathrm{C}$ were found for the as-cast alloy, while only one endothermic peak occurred at $389.7^{\circ} \mathrm{C}$ for the alloy 
Table 1. Compositions of particles within the as-cast samples (see Figure 2c) measured by EDS (at.\%).

\begin{tabular}{lccccc}
\hline Particle & $\mathrm{Mg}$ & $\mathrm{Zn}$ & $\mathrm{Zr}$ & $\mathrm{Yb}$ & Closest phase \\
\hline$A$ & 35.77 & 63.85 & 0.23 & 0.15 & $\mathrm{MgZn}_{2}$ \\
$B$ & 48.42 & 51.28 & 0.19 & 0.11 & $\mathrm{MgZn}$ \\
$C$ & 29.69 & 58.71 & 0.07 & 11.53 & $\mathrm{Mg}_{x} \mathrm{Zn}_{5} \mathrm{Yb}$ \\
$D$ & 63.45 & 36.19 & 0.15 & 0.21 & $\mathrm{Mg}_{7} \mathrm{Zn}_{3}$ \\
$E$ & 61.71 & 0.14 & 38.08 & 0.07 & $\mathrm{Zr}$ rich \\
$F$ & 96.75 & 3.15 & 0.08 & 0.02 & $\alpha-\mathrm{Mg}$ \\
\hline
\end{tabular}

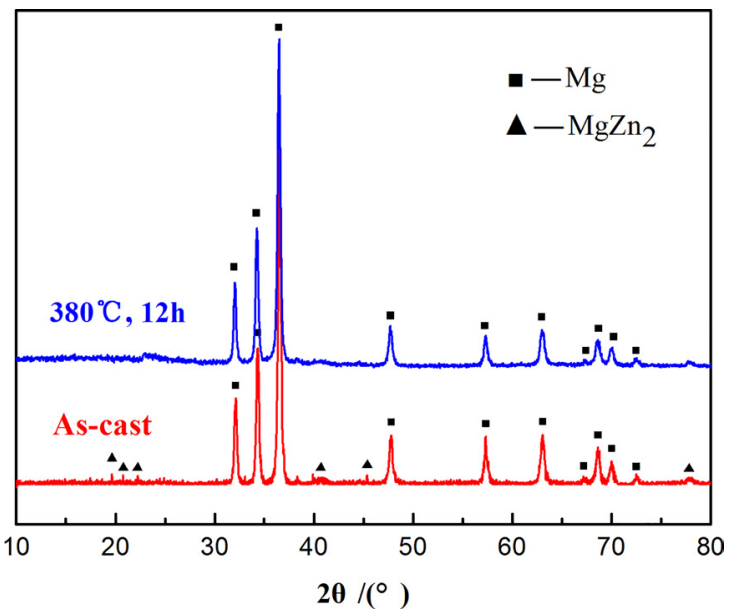

Figure 3. XRD patterns of as-cast and homogenized alloys.

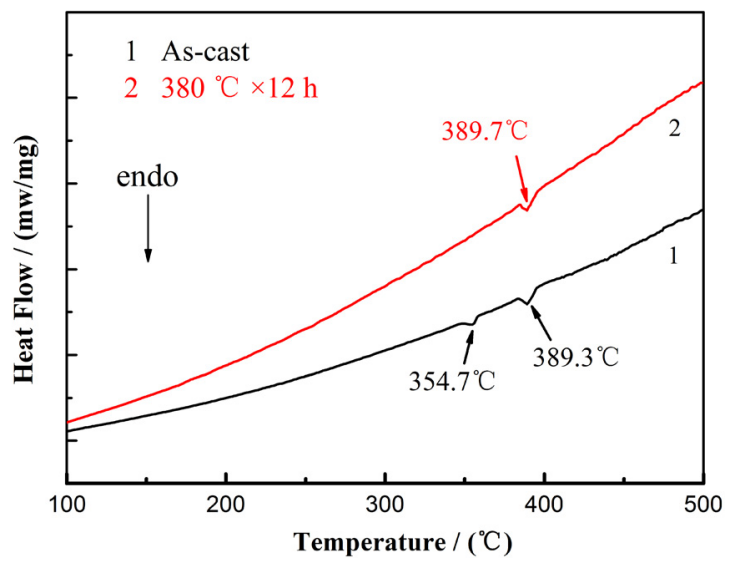

Figure 4. DSC curves of as-cast and homogenized $\left(380^{\circ} \mathrm{C} \times 12\right.$ h) alloys.

after homogenization. The first endothermic peak at $354.7^{\circ} \mathrm{C}$ probably corresponds to the eutectic temperature for $\alpha-\mathrm{Mg}$ and $\mathrm{Mg}-\mathrm{Zn}$ binary compounds $\left(347^{\circ} \mathrm{C}\right)^{25}$, and the increase of eutectic temperature may be ascribed to the addition of $\mathrm{Yb}$ which is responsible for the formation of undissolved $\mathrm{Mg}-$ $\mathrm{Zn}-\mathrm{Yb}$ ternary particles ${ }^{15}$. The second endothermic peak at $389.3^{\circ} \mathrm{C}$ may be related to the melting of $\mathrm{Mg}-\mathrm{Zn}-\mathrm{Yb}$ ternary compound. Notably, the first endothermic peak disappeared after $12 \mathrm{~h}$ homogenization at $380^{\circ} \mathrm{C}$, which indicates that the $\mathrm{MgZn}_{2}$ phase is dissolved into the matrix. However, the second endothermic peak is found at a temperature of approximately $389^{\circ} \mathrm{C}$, which illustrates that the $\mathrm{Mg}-\mathrm{Zn}-\mathrm{Yb}$ ternary phase is thermally stable during homogenization.

\subsection{Evolution of microstructure during homogenization}

Figure 5 shows the OM images after different homogenization treatments. The morphology changes from dendrites in as-cast alloy to equiaxed grains during homogenization, indicating that grain segregation is reduced substantially. As depicted in Figures 5(a), (c), (e), and (g) (figures on the left column), the microstructure evolution varies when the heat-treatment temperature increased from $360^{\circ} \mathrm{C}$ to $440{ }^{\circ} \mathrm{C}$ at a constant holding time of $8 \mathrm{~h}$. With an increase in temperature, the grains coarsen and the average grain size is increased from $32.19 \mu \mathrm{m}$ to $45.83 \mu \mathrm{m}$. However, the sample is overburnt when the homogenization temperature is increased to $440^{\circ} \mathrm{C}$. As shown in Figure 5(g), several black spots with irregular shapes are found at both boundaries and triple conjunctions, indicating that the homogenization temperature is too high for the alloy. Basing on the comparison of average grain size, the researchers found that $380{ }^{\circ} \mathrm{C}$ may be the desirable homogenization temperature for the studied alloy. Moreover, the effect of varying durations (from $4 \mathrm{~h}$ to $24 \mathrm{~h}$ ) on microstructure at a constant homogenization temperature of $380^{\circ} \mathrm{C}$ is relatively similar to that of temperature, but the impact is moderate. As illustrated in Figure 5(b), (d), (f), and (h) (figures on the right column), the grains grow evidently and their average sizes increased from $32.76 \mu \mathrm{m}$ to $55.61 \mu \mathrm{m}$ with the increase of holding time. Even though the duration increases to $24 \mathrm{~h}$, no apparent overburning phenomenon was observed in the holding time series, but its grain boundaries become thicker than other durations. Therefore, the proper holding time at a constant temperature of $380{ }^{\circ} \mathrm{C}$ is $12 \mathrm{~h}$ because the grains coarsen significantly at longer duration.

Typical SEM images of residual secondary phases after different homogenization treatments are shown in the upper right corner of Figure 5(a) to (h). The phases other than the $\alpha$ dendrites disappear gradually with heat treatment and continuous net-like structures in the as-cast alloy evolve into tiny granular precipitates in the as-homogenized sample. The average area fraction of the eutectics and the coarse phases in alloy during homogenization is introduced to evaluate 


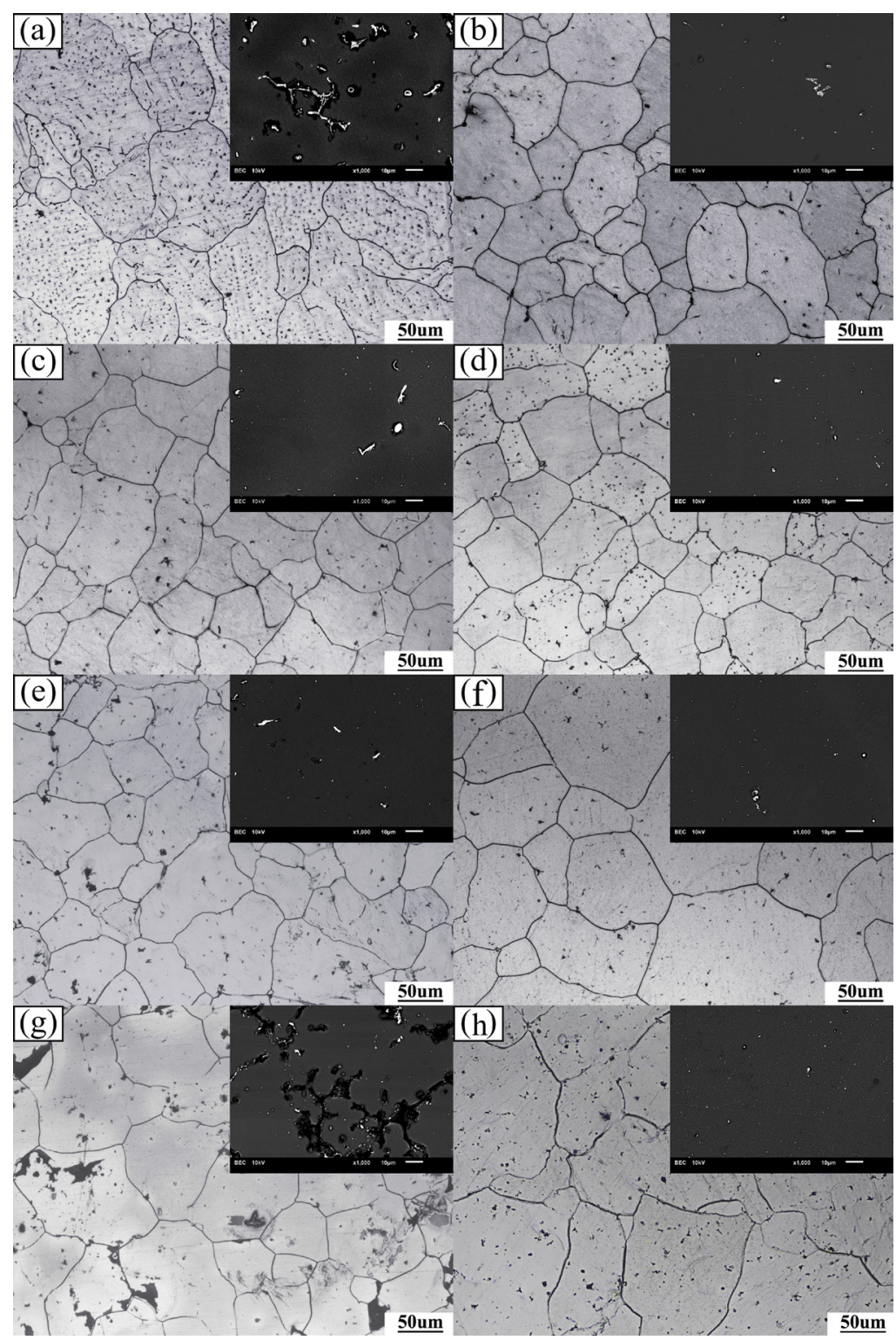

Figure 5. OM and typical SEM images of alloy homogenized for 8 hours at different temperature: (a) $360^{\circ} \mathrm{C}$, (c) $380{ }^{\circ} \mathrm{C}$, (e) $400{ }^{\circ} \mathrm{C}$, (g) $440{ }^{\circ} \mathrm{C}$ and at $380{ }^{\circ} \mathrm{C}$ for various holding time: (b) $4 \mathrm{~h}$, (d) $12 \mathrm{~h}$, (f) $16 \mathrm{~h}$, (h) $24 \mathrm{~h}$.

the influence of duration and temperature quantitatively, as depicted in Figure 6(a) and 6(b) respectively. At least 10 back-scattered SEM images are used for every point. The fraction of residual phases decreases with increasing temperature and holding time. The average area fraction decreases sharply in the initial $12 \mathrm{~h}$ at $380^{\circ} \mathrm{C}$ and changes little after further duration. The effect of temperature on the average area fraction is similar to the holding time, which decreases rapidly from $5.54 \%$ in the as-cast alloy to $1.17 \%$ at $380{ }^{\circ} \mathrm{C}$ for $8 \mathrm{~h}$ homogenization, and still reduces to $0.72 \%$ when the temperature is increased to $440{ }^{\circ} \mathrm{C}$.

By comprehensive consideration of the average grain size, microstructure morphology, overburning condition, and average area fraction of the residual secondary phase, the optimal homogenization processing of the studied alloy is determined as $380^{\circ} \mathrm{C} \times 12 \mathrm{~h}$. As demonstrated in Figure 7, a uniform and refined equiaxed grain structure is obtained and the unimodal grain size distribution is maintained with a mean grain size of $31.46 \mu \mathrm{m}$.

\subsection{Phase constituent after homogenization}

The SEM image of the alloy after homogenization at $380^{\circ} \mathrm{C}$ for $12 \mathrm{~h}$ is shown in Figure 8(a). A small quantity of tiny granular particles of approximately $\sim 1.2 \mu \mathrm{m}$ is dispersed on the substrate with one aggregation in the vision field. To 

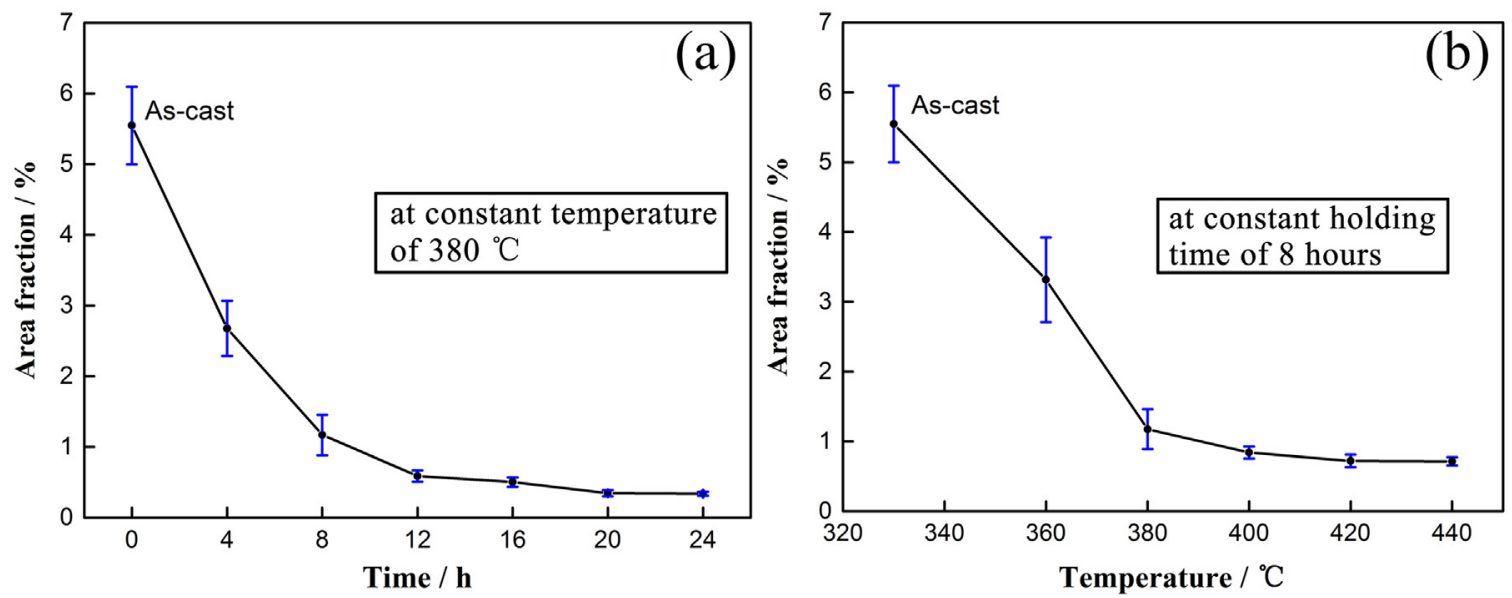

Figure 6. Evolution of average area fraction of secondary phases during homogenization (a) average area fraction versus holding time at a constant temperature of $380^{\circ} \mathrm{C}$, (b) average area fraction versus temperature at a constant holding time of $8 \mathrm{~h}$.

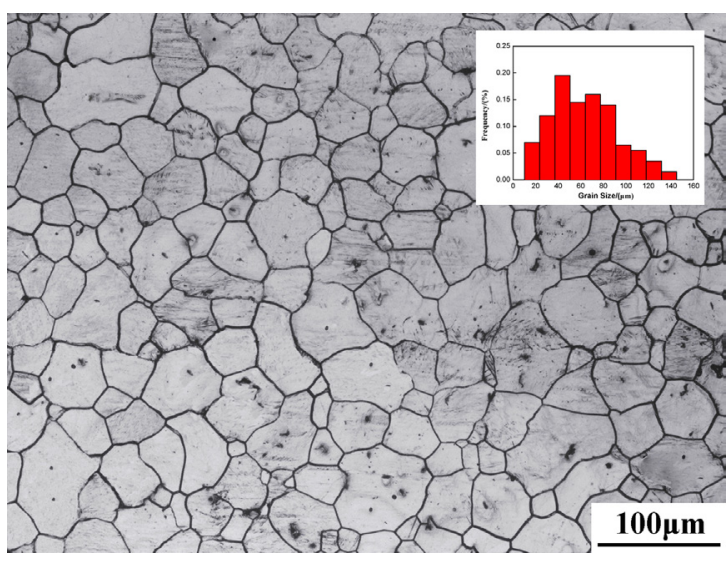

Figure 7. OM and grain size distribution images of alloys homogenized at $380{ }^{\circ} \mathrm{C} \times 12 \mathrm{~h}$
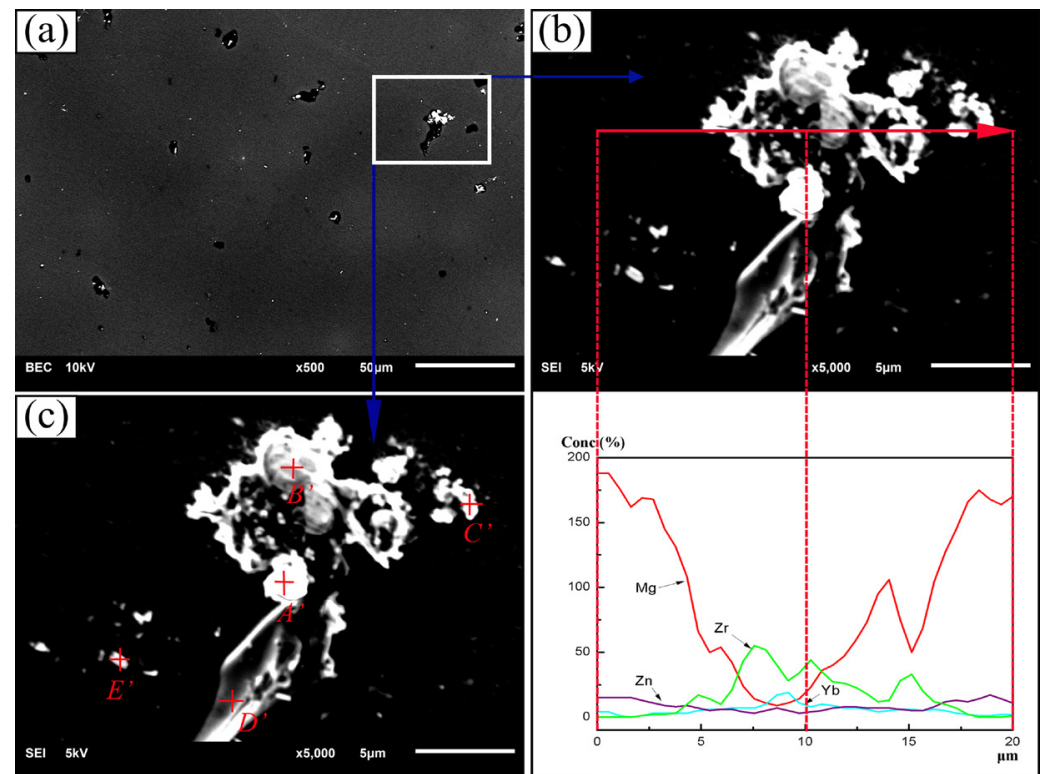

Figure 8. (a) SEM image of the phase constitution after homogenization $\left(380^{\circ} \mathrm{C} \times 12 \mathrm{~h}\right)$, (b) concentration profile of the composition across the coarse phase and (c) high magnification image of the selected area in (a), measured by EDS. verify the phase constitution and elements distribution of the undissolved white flocculus, EDS detection was performed and the compositions of five points (as shown in Figure 8(c)) are demonstrated in Table 2. Points $A$ ' and $B$ ' are rich in $\mathrm{Zr}$ but scarce in $\mathrm{Mg}, \mathrm{Zn}$, and $\mathrm{Yb}$, and are thus determined as undissolved $\mathrm{Zr}$-rich particles. Point $C^{\prime}$ is very special as it is rich in $\mathrm{Mg}$ and $\mathrm{Yb}$, but the atomic ratio cannot be found in the $\mathrm{Mg}-\mathrm{Yb}$ binary diagram. Therefore, the phase of point $C^{\prime}$ is considered as undissolved $\mathrm{Yb}$ aggregation, which existed in the solidification process but cannot be decomposed completely in subsequent homogenization. However, the $\mathrm{Yb}$ particles are rarely observed in the alloys after homogenization. Furthermore, the isolated particle far from the white flocculus, marked as $E^{\prime}$, is comprised of $\mathrm{Mg}, \mathrm{Zn}$, and $\mathrm{Yb}$. The atomic ratio of $\mathrm{Zn}$ 
Table 2. Compositions of particles within the 380 homogenized samples (see Figure 8c) measured by EDS (at.\%).

\begin{tabular}{lccccc}
\hline Particle & $\mathrm{Mg}$ & $\mathrm{Zn}$ & $\mathrm{Zr}$ & $\mathrm{Yb}$ & Closest phase \\
\hline$A^{\prime}$ & 7.54 & 0.28 & 92.17 & 0.01 & $\mathrm{Zr}$ rich \\
$B^{\prime}$ & 7.78 & 3.31 & 88.74 & 0.17 & $\mathrm{Zr}$ rich \\
$C^{\prime}$ & 37.77 & 0.48 & 0.02 & 61.73 & $\mathrm{Yb}$ rich \\
$D^{\prime}$ & 90.43 & 0.63 & 6.87 & 2.07 & $\alpha-\mathrm{Mg}$ \\
$E^{\prime}$ & 72.16 & 23.43 & 0.06 & 4.35 & $\mathrm{Mg}_{x} \mathrm{Zn}_{5} \mathrm{Yb}$ \\
\hline
\end{tabular}

and $\mathrm{Yb}$ is approximately 5:1, and can therefore be identified as $\mathrm{Mg}_{x} \mathrm{Zn}_{5} \mathrm{Yb}$ like in the as-cast alloys. The $\mathrm{Mg}_{\mathrm{x}} \mathrm{Zn}_{5} \mathrm{Yb}$ phase is revealed to always exist during the homogenization process, as it is an insoluble intermetallic phase, which cannot be eliminated by homogenization treatment. Comparing with the phase constituent of the as-cast counterparts, the researchers found that during homogenization, $\mathrm{Mg}-\mathrm{Zn}$ binary non-equilibrium phases gradually dissolve into the matrix and finally disappear after a 12-h homogenization. The element concentrations along the line profile of the white flocculus are shown in Figure 8(b). $\mathrm{Zn}$ and $\mathrm{Yb}$ both have low concentration and fluctuation. However, the content of $\mathrm{Mg}$ is higher when out of the white coarse particle, but the concentration of $\mathrm{Zr}$ has an opposite characteristic. Upon homogenization, $\mathrm{Mg}-\mathrm{Zn}$ binary phases such as $\mathrm{MgZn}_{2}, \mathrm{MgZn}$, and $\mathrm{Mg}_{7} \mathrm{Zn}_{3}$ decomposed or diffused into the matrix completely.

\subsection{Variation of microhardness during homogenization}

Vickers microhardness of specimens was measured after homogenization with different holding times at a constant temperature of $380{ }^{\circ} \mathrm{C}$ and different annealing temperature at a constant holding time of $8 \mathrm{~h}$, as shown in Figure 9(a) and (b), respectively. All microhardness values are the averages of 10 measuring points. With the increase of holding time, the hardness value is decreased sharply within the first $4 \mathrm{~h}$ and then increased steadily to the local maximum value of $64.99 \mathrm{HV}$ after 8 more hours. However, when the holding time increases

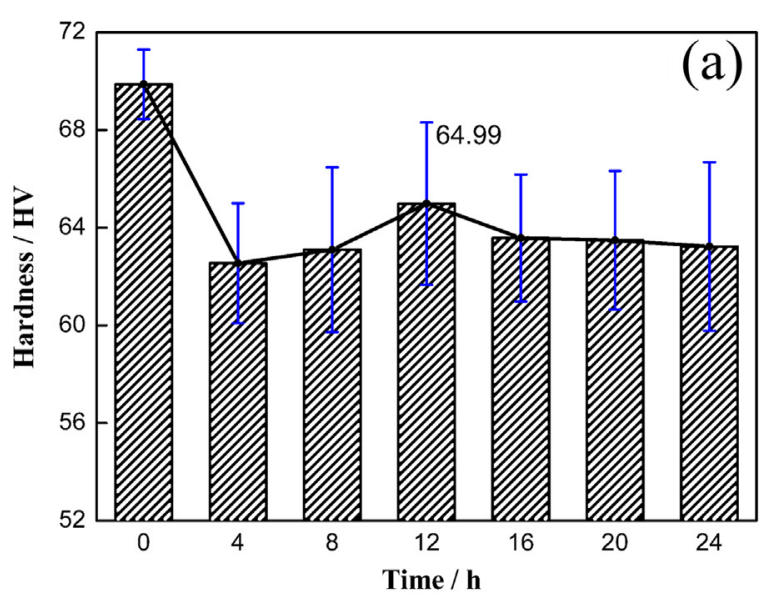

to $12 \mathrm{~h}$ or more, the hardness value is reduced slightly to 63.24 $\mathrm{HV}$. The rapid decrease of microhardness at the first $4 \mathrm{~h}$ of homogenization at $380{ }^{\circ} \mathrm{C}$ is related to the decomposition of the supersaturated solid solution and the coarse interdendritic secondary phase in as-cast alloy. Soon afterwards, owing to the nonequilibrium eutectic phases dissolving into the matrix efficiently during the next $8 \mathrm{~h}$, the microhardness is increased fairly which should derive from the solid solution strengthening effects. Furthermore, the slight decrease of the microhardness value from 12 to $24 \mathrm{~h}$ is mainly due to the substantially growing grains and the even distribution of solute atoms. Increasing the holding time will have little effect on the composition segregation, and the segregation extent will not improve further. Moreover, as depicted in Figure 9(b), with the increase of homogenization temperature from $340^{\circ} \mathrm{C}$ to $380^{\circ} \mathrm{C}$ at the constant holding time of $8 \mathrm{~h}$, the microhardness increases and the local maximum value is achieved at $380^{\circ} \mathrm{C}$. The enhancement is mainly due to the strengthening effects of the solid solution induced by the heat decomposition of nonequilibrium eutectic phases in the as-cast alloy, which is obvious in Figure 6(b) that the lowest value of area fraction is obtained at the temperature of $380^{\circ} \mathrm{C}$. In addition, the hardness decreases rapidly when the temperature is greater than $380^{\circ} \mathrm{C}$. The reason for this is that the grains grow considerably with the increase of heat input, which coincides with the metallographic observation (as shown in Figure 5). Therefore, basing on the analysis of the effect of duration and temperature on microhardness, the researchers verified the proper homogenization process, $380^{\circ} \mathrm{C} \times 12 \mathrm{~h}$, as determined in section 3.3 .

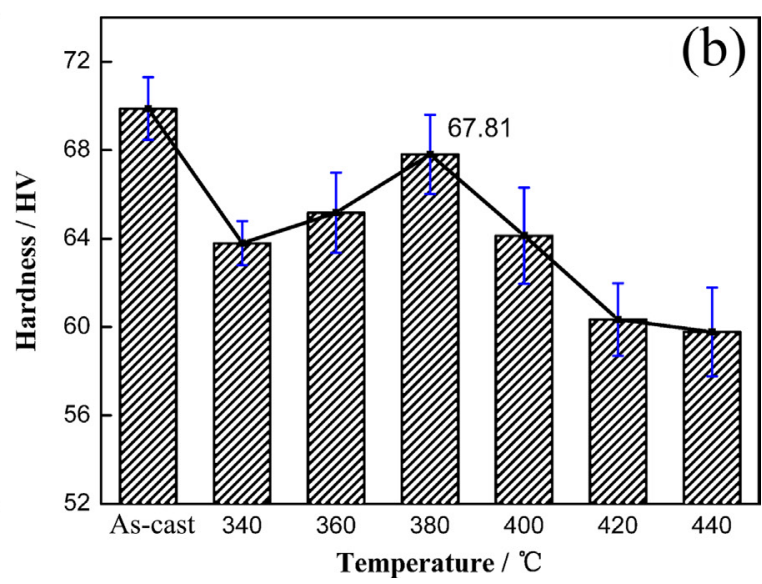

Figure 9. Evolution of Vickers microhardness after homogenization (a) microhardness versus holding time at a constant temperature of $380^{\circ} \mathrm{C}$, (b) microhardness versus temperature at a constant holding time of $8 \mathrm{~h}$. 


\section{Conclusions}

1. In the $\mathrm{Mg}-5.8 \mathrm{Zn}-0.5 \mathrm{Zr}-1.0 \mathrm{Yb}$ alloy where the $\mathrm{Yb}$ content is relatively low and thus the $\mathrm{Mg}_{2} \mathrm{Yb}$ primary phases barely form. The as-cast structure of the alloy presents typical dendritic grains with severe segregation of $\mathrm{Zr}$ in grain interiors and $\mathrm{Zn}$ as well as $\mathrm{Yb}$ at grain boundaries. The modification effect of the $\mathrm{Yb}$ addition is not evident.

2. The incorporation of $\mathrm{Yb}$ into the $\mathrm{Mg}-\mathrm{Zn}-\mathrm{Zr}$ alloy induces the precipitation of $\mathrm{Mg}_{x} \mathrm{Zn}_{5} \mathrm{Yb}$ intermetallic phase. The phase forms in the solidification process and exists in the as-cast structure. After homogenization, the $\mathrm{Mg}_{x} \mathrm{Zn}_{5} \mathrm{Yb}$ particles are retained in the structure with refined tiny granular morphology, which reveals that the ternary phase is undissolvable and cannot be eliminated by homogenization treatment.

3. Homogenization treatment at $380^{\circ} \mathrm{C}$ for $12 \mathrm{~h}$ shows a desirable improvement on the microstructure, including the grain size, precipitate morphology, quantity of residual phase, and matrix microhardness. Therefore, the treatment at $380{ }^{\circ} \mathrm{C}$ for $12 \mathrm{~h}$ is the optimized homogenization process for the $\mathrm{Mg}-5.8$ Zn-0.5 Zr-1.0 Yb alloy.

\section{Acknowledgements}

This project was financially supported by National Natural Science Foundation of China (51605392), Fundamental Research Funds for the Central Universities (XDJK2015B001).

\section{References}

1. Mordike BL, Ebert T. Magnesium: Properties - applications potential. Materials Science and Engineering: A. 2001;302(1):3745. DOI: 10.1016/s0921-5093(00)01351-4

2. Imandoust A, Barrett CD, Al-Samman T, Inal KA, El Kadiri H. A review on the effect of rare-earth elements on texture evolution during processing of magnesium alloys. Journal of Materials Science. 2017;52(1):1-29. DOI: 10.1007/s10853-016-0371-0

3. Yuan Y, Ma A, Gou X, Jiang J, Arhin G, Song D, et al. Effect of heat treatment and deformation temperature on the mechanical properties of ECAP processed ZK60 magnesium alloy. Materials Science and Engineering: A .2016;677:125-132. DOI: 10.1016/j. msea.2016.09.037

4. Yu H, Hongge Y, Jihua C, Bin S, Yi Z, Yanjin S, et al. Effects of minor gd addition on microstructures and mechanical properties of the high strain-rate rolled $\mathrm{Mg}-\mathrm{Zn}-\mathrm{Zr}$ alloys. Journal of Alloys and Compounds. 2014;586:757-765. DOI: 10.1016/j. jallcom.2013.10.005

5. Zhang J, Ma Q, Pan F. Effects of trace Er addition on the microstructure and mechanical properties of $\mathrm{Mg}-\mathrm{Zn}-\mathrm{Zr}$ alloy. Materials \& Design. 2010;31(9):4043-4049. DOI: 10.1016/j. matdes.2010.05.008
6. Xu DK, Liu L, Xu YB, Han EH. The effect of precipitates on the mechanical properties of ZK60-Y alloy. Materials Science and Engineering: A. 2006;420(1-2):322-332. DOI: 10.1016/j. msea.2006.01.092

7. Zhou HT, Zhang ZD, Liu CM, Wang QW. Effect of Nd and Y on the microstructure and mechanical properties of ZK60 alloy. Materials Science and Engineering: A. 2007;445-446:1-6. DOI: 10.1016/j.msea.2006.04.028

8. Ayman E, Junko U, Katsuyoshi K. Application of rapid solidification powder metallurgy to the fabrication of high-strength, high-ductility $\mathrm{Mg}-\mathrm{Al}-\mathrm{Zn}-\mathrm{Ca}-\mathrm{La}$ alloy through hot extrusion. Acta Materialia. 2011;59(1):273-282. DOI: 10.1016/j.actamat.2010.09.031

9. Xiao DH, Song M, Chen KH, Huang BY. Effect of rare earth $\mathrm{Yb}$ addition on mechanical properties of $\mathrm{Al}-5.3 \mathrm{Cu}-0.8 \mathrm{Mg}-0.6 \mathrm{Ag}$ alloy. Materials Science and Technology. 2007;23(10):1156-1160. DOI: $10.1179 / 174328407 X 213260$

10. Zhang XM, Wang WT, Chen MA, Gao ZG, Jia YZ, Ye LY, et al. Effects of $Y b$ addition on microstructures and mechanical properties of 2519A aluminum alloy plate. Transactions of Nonferrous Metals Society of China. 2010;20(5):727-731. DOI: 10.1016/ S1003-6326(09)60205-3

11. Jo SM, Park KC, Kim BH, Kimura H, Park SK, Park YH. Investigation on the Microstructure and Mechanical Properties of Mg-Al-Yb Alloys. Materials Transactions. 2011;52(6):1088-1095. DOI: 10.2320/matertrans.MC201011

12. Yu W, He H, Li C, Li Q, Liu Z, Qin B. Existing form and effect of zirconium in pure $\mathrm{Mg}, \mathrm{Mg}-\mathrm{Yb}$, and $\mathrm{Mg}-\mathrm{Zn}-\mathrm{Yb}$ alloys. Rare Metals. 2009;28(3):289-296. DOI: 10.1007/s12598-009-0057-8

13. Yamasaki M, Hayashi N, Izumi S, Kawamura Y. Corrosion behavior of rapidly solidified $\mathrm{Mg}-\mathrm{Zn}$-rare earth element alloys in $\mathrm{NaCl}$ solution. Corrosion Science. 2007;49(1):255-262. DOI: 10.1016/j.corsci.2006.05.017

14. Yu WB, Chin ZQ, Cheng NP, Gan BT, He H, Li XL, et al. Highstrength wrought magnesium alloy with dense nano-scale spherical precipitate. Chinese Science Bulletin. 2007;52(13):1867-1871. DOI: $10.1007 / \mathrm{s} 11434-007-0250-9$

15. Yu W, Liu Z, He H, Cheng N, Li X. Microstructure and mechanical properties of ZK60-Yb magnesium alloys. Materials Science and Engineering: A. 2008;478(1-2):101-107. DOI: 10.1016/j. msea.2007.09.027

16. Monachon C, Krug ME, Seidman DN, Dunand DC. Chemistry and structure of core/double-shell nanoscale precipitates in Al-6.5Li0.07Sc-0.02Yb (at.\%). Acta Materialia. 2011;59(9):3398-3409. DOI: 10.1016/j.actamat.2011.02.015

17. Zhang Z, Chen KH, Fang HC, Qi XW, Liu G. Effect of Yb addition on strength and fracture toughness of $\mathrm{Al}-\mathrm{Zn}-\mathrm{Mg}-\mathrm{Cu}-\mathrm{Zr}$ aluminum alloy. Transactions of Nonferrous Metals Society of China. 2008;18(5):1037-1042. DOI: 10.1016/S1003-6326(08)60177-6

18. Chen KH, Fang HC, Zhang Z, Chen X, Liu G. Effect of of Yb, $\mathrm{Cr}$ and $\mathrm{Zr}$ additions on recrystallization and corrosion resistance of $\mathrm{Al}-\mathrm{Zn}-\mathrm{Mg}-\mathrm{Cu}$ alloys. Materials Science and Engineering: A. 2008;497(1-2):426-431. DOI: 10.1016/j.msea.2008.07.028

19. Wei XL, Lian Z, Zhao HZ, Li L, Yu WB. Modification effect of $\mathrm{Yb}$ and $\mathrm{Na}_{3} \mathrm{PO}_{4}$ on microstructure of $\mathrm{Mg}_{2} \mathrm{Si} / \mathrm{Mg}-4 \mathrm{Si}$ alloy and mechanism. China Foundry. 2015;12(6):440-445. 
20. Li B, Wang H, Jie J, Wei Z. Microstructure evolution and modification mechanism of the ytterbium modified Al$7.5 \% \mathrm{Si}-0.45 \% \mathrm{Mg}$ alloys. Journal of Alloys and Compounds. 2011;509(7):3387-3392. DOI: 10.1016/j.jallcom.2010.12.081

21. Yan H, Chen F, Li Z. Microstructure and mechanical properties of AlSi10Cu3 alloy with ( $\mathrm{La}+\mathrm{Yb})$ addition processed by heat treatment. Journal of Rare Earths. 2016;34(9):938-944. DOI: 10.1016/S1002-0721(16)60118-7

22. Fang HC, Chen KH, Zhang Z, Zhu CJ. Effect of Yb additions on microstructures and properties of 7A60 aluminum alloy. Transactions of Nonferrous Metals Society of China. 2008;18(1):28-32. DOI: 10.1016/S1003-6326(08)60006-0
23. Zhao MC, Deng YL, Zhang XM. Strengthening and improvement of ductility without loss of corrosion performance in a magnesium alloy by homogenizing annealing. Scripta Materialia. 2008;58(7):560-563. DOI: 10.1016/j.scriptamat.2007.11.023

24. Zhao MC, Liu M, Song GL, Atrens A. Influence of Homogenization Annealing of AZ91 on Mechanical Properties and Corrosion Behavior. Advanced Engineering Materials. 2008;10(1-2):93103. DOI: 10.1002 /adem.200700234

25. Bhan S, Lal A. The Mg-Zn-Zr system (magnesium-zinczirconium). Journal of Phase Equilibria. 1993;14(5):634-637. DOI: 10.1007/BF02669156 